\title{
Reproductive cycles of dominant calanoid copepods in the North Sea
}

\author{
C. Halsband, H. J. Hirche* \\ Alfred Wegener Institute for Polar and Marine Research, Columbusstraße 1, 27568 Bremerhaven, Germany
}

\begin{abstract}
The seasonal cycles of reproduction of the dominant copepods Acartia clausi, Temora longicornis, Centropages hamatus, C. typicus and Pseudocalanus spp. were studied at Helgoland Roads, southern North Sea. Egg production rate, clutch size, number of spawning females and prosome length were compared with temperature and phytoplankton concentration. Female A. clausi, T. longicornis and Pseudocalanus spp. were present all year round. T. longicornis and Pseudocalanus spp. bred continuously throughout the year, although egg production rates and the proportion of spawning females were low in winter. A. clausi did not spawn between the end of September and the end of January. Female C. hamatus were absent from the water column from November to May, and C. typicus from February to August. As the latter 3 species spawn year round in warmer regions, low temperature inhibition of reproduction is suggested for Helgoland, where winter temperatures are below $0^{\circ} \mathrm{C}$. Maximum egg production was observed in all species, except the late-arriving C. typicus, in April/May, when females were largest. Significant correlations were only obtained between clutch size or egg production rate and prosome length, which in turn was correlated with temperature. It is therefore concluded that for Helgoland waters temperature controlled egg production by its effect on prosome length, and that food conditions were not limiting.
\end{abstract}

KEY WORDS: North Sea · Reproduction · Egg production · Acartia clausi - Temora longicornis · Centropages hamatus $\cdot$ C. typicus $\cdot$ Pseudocalanus spp.

\section{INTRODUCTION}

Knowledge of the reproductive biology is a prerequisite to understanding population dynamics and production. In copepods, the timing of reproduction determines the annual productive cycle. As copepod eggs and nauplii are a favourite food source for the larvae of a number of commercially important fishes, copepod reproduction also affects fish recruitment. According to the concept of niche separation, co-occurring species should differ in resource-partitioning or, when using the same resources, they should separate seasonally. Examples for seasonal succession of species probably caused by different patterns of reproduction are found in a number of coastal/neritic systems: Eury-

\footnotetext{
*Corresponding author. E-mail: hhirche@awi-bremerhaven.de
}

temora affinis/Acartia tonsa (Hirche 1992), A. longiremis/A. clausi (Eriksson 1973, Ianora \& Buttino 1990), and multi-species succession (Raymont 1983). On the other hand, Kiørboe \& Nielsen (1994) observed synchronous peaks in egg production for several calanoid copepod species in the Kattegat, following peaks of phytoplankton abundance.

In laboratory studies with females from 1 population, temperature and food conditions are the key factors controlling egg production of calanoid copepods (Dagg 1978, Landry 1978, Uye 1981, Smith \& Lane 1985, Hirche et al. 1997). In the field, in regions with multiple generations, female size also affects egg production (Hirche 1992). Female size, in turn, may depend on food (Mullin \& Brooks 1970) and temperature (Corkett $\&$ McLaren 1978). The interaction between these factors is not easily understood (Bautista et al. 1994). While studies over larger time scales indicate tempera- 
ture limitation of breeding (Ambler 1986, Kiørboe et al. 1988), in studies over shorter time scales food availability seems to be more important (Runge 1984, Beckman \& Peterson 1986, Kiørboe et al. 1988). Thus, food limitation of egg production is frequently observed in the field (Peterson et al. 1991, Tiselius et al. 1991, Niehoff et al. 1999). Temperature may be important via its effect on body size in species having multiple generations in locations with a wide amplitude of temperatures (Landry 1978, Hirche 1992, Ban 1994).

In the southern North Sea, a number of small calanoida (Acartia clausi, Temora longicornis, Centropages hamatus, C. typicus and Pseudocalanus spp.) dominate the zooplankton population during a large part of the year (Fransz 1975, 1983a,b, Hickel 1975). These species show different seasonal distribution patterns, in which 'colder' species such as $T$. longicornis and $C$. hamatus precede the 'warmer' A. clausi and C. typicus (Fransz \& van Arkel 1983). Unfortunately, in this region their seasonal reproductive cycles have not yet been described and most studies have been over short time scales such as that of Daan (1989) in the Southern Bight. Bautista et al. (1994) followed copepod fecundity south of Plymouth during 2 spring blooms. Closer to Helgoland, only the study of Kiørboe \& Nielsen (1994) in the Kattegat has pursued the breeding behaviour of copepods over a whole seasonal cycle. Kiørboe \& Johansen (1986) investigated copepod productivity in the Buchan area in September. Peterson et al. (1991) studied egg production in the Skagerrak in August, while Tiselius et al. (1991) examined the same area from May to June. The study of Hay (1995) covered the whole North Sea, but was restricted to 5 cruises.

Here we wanted to describe a complete annual cycle of copepod egg production and the factors controlling it at a time-series station at Helgoland Roads, Helgoland Island (southern North Sea). In this paper, we relate food, temperature and female size to rates of in situ egg production of the 5 dominant species. Diatom carbon and total phytoplankton carbon are used as estimates of food. We mostly used measurements on individual females to determine individual and population egg production rate, clutch size, and number of females actively spawning. We tested the hypothesis that all species respond similarly to changes in the food environment (Kiørboe \& Nielsen 1994).

\section{MATERIALS AND METHODS}

Sampling. Plankton was collected at 'Helgoland Roads' (Fig. 1: $54^{\circ} 11.3^{\prime} \mathrm{N}, 7^{\circ} 54.0^{\prime} \mathrm{E}$ ) on $83 \mathrm{~d}$ between July 1995 and August 1996. Sampling was conducted in the morning by horizontal CALCOFI net tows $(280 \mu \mathrm{m}$ mesh) for ca $10 \mathrm{~min}$ at a water depth of ca $10 \mathrm{~m}$. The samples were gently diluted in $10 \mathrm{l}$ of unfiltered seawater and brought to the laboratory within $1 \mathrm{~h}$. Live adult females were sorted out under a binocular microscope. Part of the sample was preserved in $4 \%$ buffered formalin. The prosome length of 15 to 50 specimens per species was measured for females taken from preserved samples once or twice per month with a video-image digitising system (NIH Image 1.55). Temperature, salinity and phytoplankton distribution were measured on all working days at the surface by the Biological Oceanography Group of the Biologische Anstalt Helgoland (Hickel et al. 1997, Hickel 1998).

Egg production measurements. Egg production experiments were conducted with the dominant species Acartia clausi, Temora longicornis, Centropages hamatus and C. typicus. The genus Pseudocalanus was examined only from November 1995; we did not try to distinguish species. For egg production measurements, 20 to 30 females of each species were kept individually in cell wells (Corning) filled with $3 \mathrm{ml}$ of screened $(50 \mu \mathrm{m})$ seawater. They were incubated for $24 \mathrm{~h}$ in cold rooms at ambient temperatures. For some experiments with $A$. clausi, females were incubated for up to $3 \mathrm{~d}$. Surplus food (Dunaliella tertiolecta grown in f/2 medium) was added daily; control intervals varied between 4 and $12 \mathrm{~h}$. Light was provided by daylight bulbs over a 12/12 h light/dark cycle. The wells were inspected 2 to 3 times during the day, and eggs were counted and removed in order to avoid egg cannibalism. Empty egg shells were included in the egg counts.

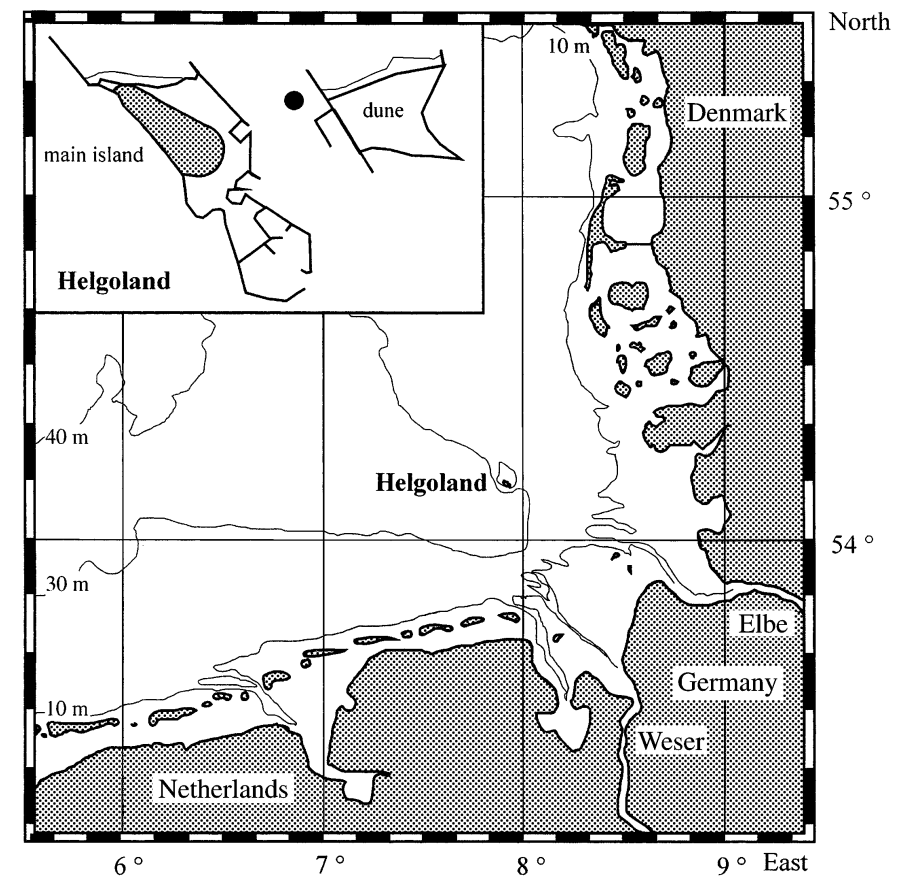

Fig. 1. Location of sampling station, Helgoland Roads, southern North Sea 
Egg production and clutch size of Pseudocalanus spp. were determined by detaching the egg sacs, breaking them up, and counting the eggs. To determine clutch size, control intervals had to be shorter than the spawning intervals, which, in turn, are temperaturedependent (Hirche et al. 1997). Therefore, intervals between inspections were never longer than $12 \mathrm{~h}$.

\section{RESULTS}

\section{Hydrography}

The sampling station, Helgoland Roads in the German Bight, is characterized by strong currents and is therefore never stratified (Radach et al. 1990). In summer, the hydrography is strongly influenced by freshwater input through run-off from the rivers Elbe and Weser into the German Bight. In autumn and winter, Atlantic water masses reach Helgoland from the north and the English Channel (Goldberg 1973, Banner et al. 1980, Otto et al. 1990). This is reflected in the annual cycle of salinity during our sampling period (Fig. 2a). Salinity showed lowest values between April
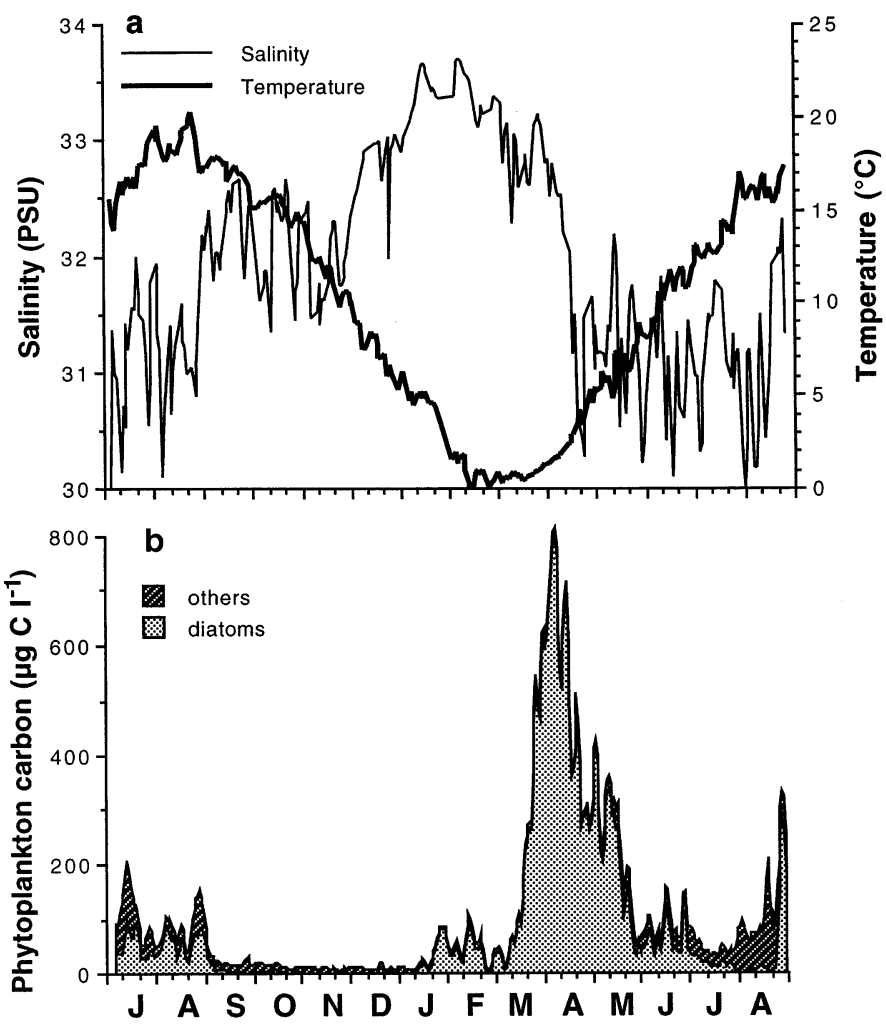

Fig. 2. Seasonal cycles of (a) temperature and salinity and (b) phytoplankton at Helgoland Roads. 'others' = total phytoplankton carbon - diatom carbon. Phytoplankton data smoothed by 3-point running average and July; thereafter it increased continuously to a maximum in January. Maximum temperature was higher in August $1995\left(20.2^{\circ} \mathrm{C}\right)$ than in $1996\left(18.5^{\circ} \mathrm{C}\right)$. The winter 1995/1996 was severe, with ice cover in the Wadden Sea; around Helgoland, temperatures dropped to a minimum of $-0.5^{\circ} \mathrm{C}$ on 9 February 1996 .

\section{Phytoplankton}

The seasonal cycle of diatom carbon and all other phytoplankton carbon is presented in Fig. 2b. A diatom bloom, consisting of Coscinodiscus wailesii, started in January during a period of high atmospheric pressure. The spring-bloom maximum was observed at the end of March/beginning of April 1996. Thereafter diatoms decreased continuously to a minimum in July, followed by another increase at the end of our investigation period. This is in contrast to 1995, when diatoms decreased from July to September. Non-diatom phytoplankton, mainly peridinids, increased continuously from April to August 1996.

\section{Reproductive cycles}

\section{Acartia clausi}

Female Acartia clausi were always present in the samples, and experiments were conducted on $60 \mathrm{~d}$. The average rates of egg release by individual females per day at in situ temperatures are shown in Fig. 3. The reproductive period lasted from February to October; from October to the end of January only very few females were spawning, mostly at very low rates. In February already $60 \%$ of the females were producing eggs. Highest egg production rates were observed in July and August 1995 and from May to July 1996 (Fig. 3b). The maximum daily mean egg production rate was 33.5 eggs female $\mathrm{e}^{-1} \mathrm{~d}^{-1}$ in mid-June 1996, and the highest individual rate was 57 eggs female ${ }^{-1} \mathrm{~d}^{-1}$. In the other months, egg production was relatively low (Fig. 3b). This was due to low individual egg production rates rather than to a low number of spawning females (Fig. 3c). Reproductive activity decreased rapidly in September, when $>50 \%$ of the females were immature. Unlike the other species investigated, A. clausi deposited low numbers of eggs, sometimes at intervals of a few hours (Fig. 3a), similar to A. tonsa (Parrish \& Wilson 1978). A. clausi underwent a strong seasonal variability in prosome length, the monthly mean ranging from 770 to $1040 \mu \mathrm{m}$ and individual extremes from 650 to $1140 \mu \mathrm{m}$. The largest females were found in June, and the smallest ones in September (Fig. 3d). 


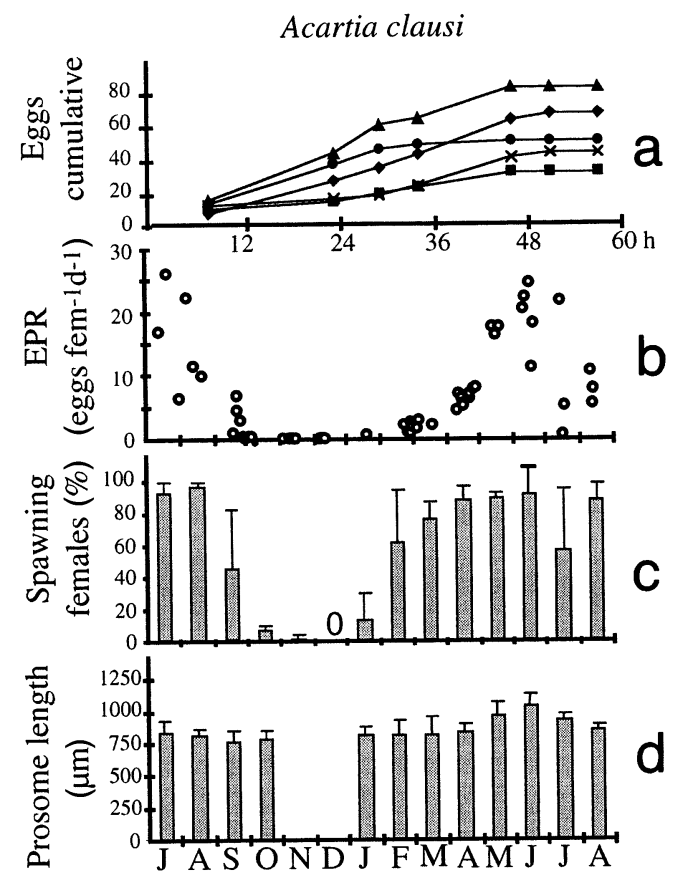

Fig. 3. Acartia clausi. Reproductive parameters at Helgoland Roads. (a) Cumulative egg production (eggs female ${ }^{-1}$ ) of 5 individuals during a $2.5 \mathrm{~d}$ period; (b) egg production rate, $\mathrm{EPR}_{i}(\mathrm{c})$ proportion of females spawning; (d) prosome length

\section{Temora longicornis}

Temora longicornis reproduced throughout the whole year (Fig. 4a), and observations are available for $69 \mathrm{~d}$. Reproductive activities were at their minimum in December and January, when only ca $20 \%$ of the females were spawning. Egg production rates and clutch sizes (Fig. 4a,b) showed a pronounced annual cycle, with peak values from the end of April to the end of July. The highest daily mean rate was measured in May at 62 eggs female ${ }^{-1} \mathrm{~d}^{-1}$, and the highest individual egg production was 122 eggs female $\mathrm{e}^{-1} \mathrm{~d}^{-1}$. In winter, the rate of egg production was reduced to $<10$ eggs female ${ }^{-1} \mathrm{~d}^{-1}$ (Fig. 4a). T. longicornis produced clutches, which stuck together for some time after deposition. Individual clutch size was highly variable, with a maximum of 56 eggs per clutch and followed the seasonal cycle of egg production rate closely (Fig. 4b). The monthly mean prosome length of female $T$. longicornis varied between 875 and $1220 \mu \mathrm{m}$, with individual extremes of 790 and $1360 \mu \mathrm{m}$. The largest females were found in April, and the smallest ones in October (Fig. 4d).

\section{Centropages hamatus}

Adult Centropages hamatus occurred only from April to November, and egg production was measured on only $30 \mathrm{~d}$. C. hamatus produced eggs on all sampling dates. The eggs were spiny, and stuck together several hours after spawning. This species had the highest egg production rates of all species examined. Females reached maximum daily mean reproduction values in May/June, with 95 eggs female $\mathrm{f}^{-1} \mathrm{~d}^{-1}$ (Fig. 4a), and the individual maximum was 153 eggs female ${ }^{-1} \mathrm{~d}^{-1}$. Later in the year, egg production decreased continuously, until females disappeared from the samples. Maximal clutch size (75 eggs per clutch) was reached in May, and clutch sizes decreased steadily thereafter (Fig. 4b). C. hamatus was the biggest species, with the largest size range. Prosome length varied in individuals by a factor of 2, from $750 \mu \mathrm{m}$ in October to $1570 \mu \mathrm{m}$ in May, while monthly mean size varied from 880 to $1330 \mu \mathrm{m}$ (Fig. 4d).

\section{Centropages typicus}

The congener Centropages typicus showed up in the samples only in September and was found until January. It was studied on $21 \mathrm{~d}$. The maximum daily mean egg production rate (35 eggs female ${ }^{-1} \mathrm{~d}^{-1}$ ) was much lower than that of $C$. hamatus, and so was the highest individual egg production rate (104 eggs female $\mathrm{f}^{-1} \mathrm{~d}^{-1}$ ). Within a few weeks of the species appearing, reproduction had already decreased dramatically, and nearly ceased from November onward (Fig. 4a). Eggs were morphologically similar to those of $C$. hamatus, but with small spines. The largest single clutch contained 81 eggs compared to 75 in C. hamatus (Fig. 4b). Not all females found were reproducing. The percentage of spawning females varied from 15 to $50 \%$ (Fig. 4c). In January the last specimens were found, and C. typicus then disappeared again. Female length in $C$. typicus ranged from 900 to $1300 \mu \mathrm{m}$ for individuals, and from 1020 to $1230 \mu \mathrm{m}$ for the monthly mean. The females were largest in September (Fig. 4d).

\section{Pseudocalanus spp.}

The genus Pseudocalanus is presumed to be represented by at least 2 species in the North Sea - P. elongatus and $P$. acuspes (Frost 1989), but we are not aware of any field study in which they were actually distinguished. At Helgoland Roads, Pseudocalanus spp. were among the most abundant copepods. Length-frequency histograms did not show any modality as an indicator for different species. Therefore, we treated all Pseudocalanus as a genus. Our investigation of this genus started only in November 1996. Experiments were conducted on 27 d. Female Pseudocalanus spp. carry their eggs in sacs until the nauplii hatch. In this study only 


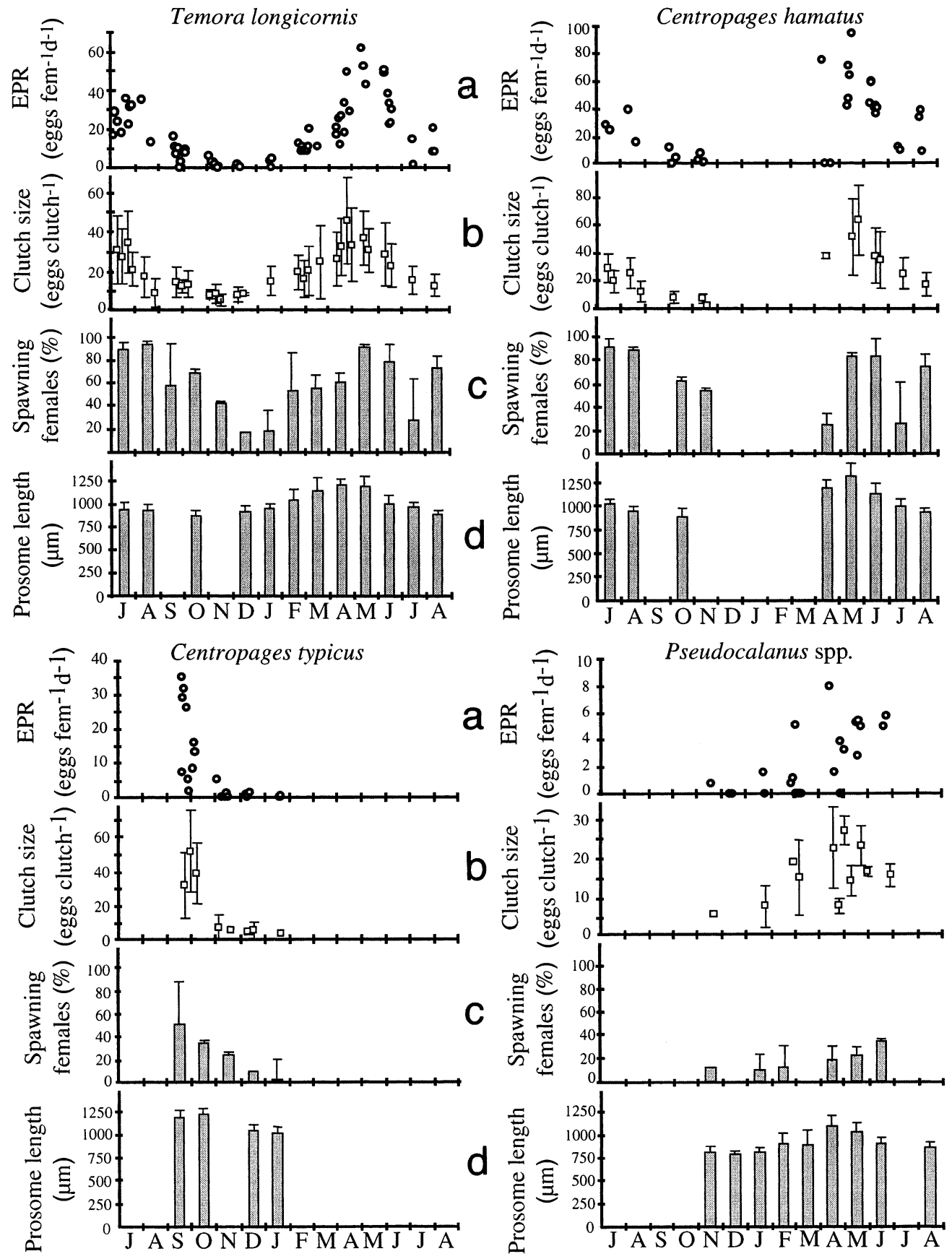

Fig. 4. Temora longicornis, Centropages hamatus, C. typicus and Pseudocalanus spp. Reproductive parameters at Helgoland Roads. (a) Egg production rate; (b) clutch size, weekly means \pm SD; (c) proportion of females spawning; (d) prosome length

egg sacs produced during the incubation period were counted, as many detached egg sacs were found in the samples. The percentage of spawning females never exceeded $35 \%$ (Fig. 4c). Egg laying occurred throughout the investigation period, except in December and March, when females were scarce (Fig. 4a). Highest egg production rates were observed in April and May, with a maximum daily mean of 8 eggs female ${ }^{-1} \mathrm{~d}^{-1}$ in May. Clutch size varied from 5 to 38, with the largest clutches found from the end of February to mid-May (Fig. 4b). Monthly mean prosome length varied between 790 and $1100 \mu \mathrm{m}$, and individual size ranged from 680 to $1340 \mu \mathrm{m}$ (Fig. 4d). The largest females were found in April. 


\section{Factors controlling egg production}

Egg production rates of several species were significantly correlated with each other (Table 1), indicating a common factor controlling their spawning activity. In Table 2 the correlation coefficients of linear regression between temperature, phytoplankton components, body size and egg production or clutch size are presented. As Centropages typicus spawned only during a period of $16 \mathrm{~d}$, it was not considered here.

In the species investigated here, an increase in temperature paralleled an increase in egg production rate only during the spring. Thereafter, egg production rate decreased in all species, while temperature continued to increase (Figs. 2 to 4 ). Consequently, neither correlations between clutch size and temperature nor between temperature and egg production rate were significant (Table 2). However, comparison of monthly mean female prosome length with the seasonal cycle of temperature indicated an inverse relationship in all species except Centropages typicus (Fig. 5), with the maxima and minima of length lagging behind the respective minima and maxima of temperature. This lag was most likely due to the fact that adult body size is the result of the temperature conditions prevailing during larval development (Hart \& McLaren 1978). Thus, in a period of increasing temperature the specimens would have developed at lower temperatures than those prevailing at collection; during a period of decreasing temperature they would have developed at higher temperatures than those prevailing at collection. This is reflected in the regression analysis, which indicates that only Temora longicornis and C. hamatus showed significant relationships between temperature and body size.

Although the same constraints as for the temperature-body size relationship hold also for the food-body size relationship, highly significant relationships were found between diatom carbon, total phytoplankton carbon and body size in Acartia clausi, Temora longicornis and Pseudocalanus spp. (Table 2). However, the correlation coefficients were higher for temperature versus body size except for Pseudocalanus spp.

The seasonal variability of clutch size and egg production rate followed closely seasonal changes in body size (Figs. 3 to 5). Hence, highly significant relationships were found between clutch size and/or egg production rate in Acartia clausi, Temora longicornis and Centropages hamatus, but not in Pseudocalanus spp. (Table 2).

Table 1. Correlation coefficients $\left(\mathrm{r}^{2}\right)$ between egg production rates of 4 copepod species. Sample size in parentheses. Significance levels $={ }^{* *} \mathrm{p}<0.001{ }^{* * *} \mathrm{p}<0.0001$

\begin{tabular}{|lcccc|}
\hline & Temora longicornis & Centropages hamatus & Centropages typicus & Pseudocalanus spp. \\
\hline Acartia clausi & $0.578^{* * *}(48)$ & $0.415^{* *}(16)$ & $0.346^{* *}(15)$ & $0.676^{* * *}(19)$ \\
Temora longicornis & - & $0.568^{* * *}(25)$ & $0.763^{* * *}(18)$ & $0.519^{* * *}(19)$ \\
Centropages hamatus & - & $0.111(5)$ & $0.021(6)$ \\
Centropages typicus & & & - & no data \\
\hline
\end{tabular}

Table 2. Acartia clausi, Temora longicornis, Centropages hamatus and Pseudocalanus spp. Correlation coefficients $\left(\mathrm{r}^{2}\right)$ between temperature at collection $(\mathrm{T})$, prosome length (PL), clutch size (CL), egg production rate (EPR), diatom carbon (Diat), non-diatom carbon (NonDiat), and total phytoplankton carbon (PPC) at Helgoland Roads. In A. clausi clutch size = daily egg production rate of spawning females. Sample size in parentheses. Significance levels $={ }^{*} \mathrm{p}<0.01 ;{ }^{* *} \mathrm{p}<0.001 ;{ }^{* * *} \mathrm{p}<0.0001$

\begin{tabular}{|c|c|c|c|c|}
\hline Parameter & A. clausi & T. longicornis & C. hamatus & Pseudocalanus spp. \\
\hline T/PL & $0.052(60)$ & $0.514^{* * *}(69)$ & $0.851^{* * *}(33)$ & $0.148(27)$ \\
\hline $\mathrm{T} / \mathrm{CL}$ & $0.001(57)$ & $0.076(64)$ & $0.163(30)$ & $0.112(16)$ \\
\hline T/EPR & $0.023(60)$ & 0.017 (69) & $0.082(33)$ & $0.086(27)$ \\
\hline Diat/PL & $0.004(60)$ & $0.433^{* * *}(69)$ & $0.278^{*}(33)$ & $0.665^{* * *}(27)$ \\
\hline NonDiat/PL & $0.042(60)$ & $0.200(69)$ & $0.033(33)$ & $0.001(27)$ \\
\hline $\mathrm{PPC} / \mathrm{PL}$ & $0.001(60)$ & $0.354^{* * *}(69)$ & $0.179(33)$ & $0.670^{* * *}(27)$ \\
\hline PL/CL & $0.765^{* * *}(57)$ & $0.396^{* * *}(64)$ & $0.774^{* * *}(30)$ & $0.247(16)$ \\
\hline PL/EPR & $0.839^{* * *}(60)$ & $0.099(69)$ & $0.660^{* * *}(33)$ & - \\
\hline Diat/EPR & $0.004(60)$ & $0.071(69)$ & $0.010(33)$ & $0.001(27)$ \\
\hline NonDiat/EPR & $0.091(60)$ & 0.039 (69) & $0.026(33)$ & $0.095(27)$ \\
\hline PPC/EPR & $0.010(60)$ & 0.118 (69) & $0.126(33)$ & $0.137(27)$ \\
\hline Diat/CL & $0.021(57)$ & $0.292^{*}(64)$ & $0.191(30)$ & $0.027(16)$ \\
\hline NonDiat/CL & $0.146^{*}(57)$ & $0.076(64)$ & $0.020(30)$ & $0.058(16)$ \\
\hline $\mathrm{PPC} / \mathrm{CL}$ & $0.005(57)$ & $0.317^{* * *}(64)$ & $0.172(30)$ & $0.240(16)$ \\
\hline
\end{tabular}


a
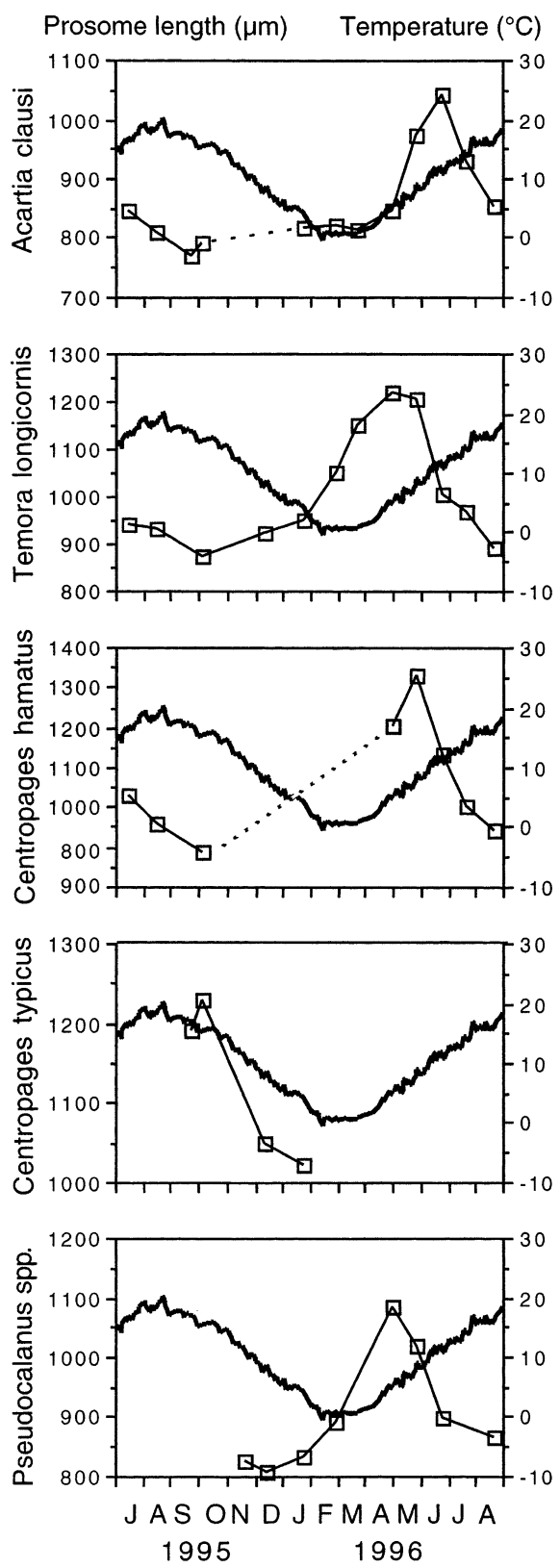

Fig. 5. Acartia clausi, Temora longicornis, Centropages hamatus, C. typicus, Pseudocalanus spp. Seasonal cycles of (a) temperature and prosome length (monthly means) and (b) prosome length (continuous line, from monthly means) and clutch size at Helgoland Roads. In A. clausi, clutch size = daily egg production rate of all spawning females. In (b) seasonal cycle of phytoplankton carbon (PPC) is added (dashed line, 3-point running average)

There were clear differences in the timing of reproductive activity of the 3 spring-spawning species Acartia clausi, Temora longicornis, and Pseudocalanus spp. with respect to phytoplankton development (Figs. 2 to 5). In A. clausi, egg production increased during the diatom peak and reached a maximum 2 mo later. Egg production and clutch size of $T$. longicornis increased before the spring diatom increase and reached its maxi- mum 1 mo after the phytoplankton peak. High egg production was observed in Pseudocalanus spp. before the bloom and several weeks after the bloom. The continuous increase in the non-diatom component of phytoplankton biomass towards the end of the study period was not reflected in the egg production rates of any species (Figs. 2 to 4 ). Hence, there is no significant relationship ( $p<0.01$ ) between egg production rate and any of the indices of food concentration (Table 2); however, there are significant relationships of diatom and phytoplankton carbon with clutch size in T. longicornis (Table 2).

\section{DISCUSSION}

\section{Seasonal reproductive cycles and reproductive strategies}

At Helgoland Roads, Acartia clausi, Temora longicornis and Pseudocalanus spp. were present throughout the year, whereas the 2 Centropages congeners showed a summer/winter succession. C. typicus is considered an immigrant which is brought regularly to the North Sea in autumn by advection of Atlantic waters (Raymont 1983, Fransz et al. 1991). This species occurred only at the end of September, when the other species had more or less completed reproduction. Female C. hamatus first appeared in April and were present until the end of October. The annual abundance patterns of the 5 species confirm the current view of these species (reviewed by Krause et al. 1995), which together contribute ca $85 \%$ of the total zooplankton biomass in the Dutch and German Wadden Sea (Hickel 1975).

The general patterns of the annual reproductive cycle of 4 of the 5 copepod species studied here were surprisingly similar, with peaks in egg production rate between the end of April and June and much lower rates during the other months. One exception was Centropages typicus, which had its highest egg production rates in the first week of its occurrence in the plankton, in the middle of September. The similarity of 
the reproductive patterns is the more surprising, as the 4 species differ considerably in their life history and reproductive strategies in the North Sea. The most striking differences between species concerned the presence of females and the duration of the spawning period. Acartia clausi, Temora longicornis and Pseudocalanus spp. females were present all year round. Of these species, T. longicornis and probably also Pseudocalanus spp. continuously bred throughout the year, although egg production rates and the proportion of spawning females were low in winter. Similar observations were reported from the Kattegat by Kiørboe \& Nielsen (1994). T. longicornis is known to produce resting eggs in addition to subitaneous eggs (Lindley 1986, 1990).

Adult females were the main overwintering stage of Acartia clausi. They did not spawn between the end of September and the end of January. This was longer than in the Kattegat, where reproduction ceased only between October and December (Kiørboe \& Nielsen 1994). In contrast, in warmer regions such as the Mediterranean Sea, A. clausi reproduces year round, with winter and spring as the main spawning season (Gaudy 1972, Ianora \& Scotto di Carlo 1988, Ianora \& Buttino 1990). Continuous reproduction was also observed in a lagoon in the eastern Pacific (Landry 1978). It is not known whether the females undergo a dormancy during winter similarly to A. longiremis (Davis 1976, Norrbin 1996). Resting eggs of the genus Acartia were found in North Sea sediments (Lindley 1990). Kasahara et al. (1974) suggested that A. clausi produces resting eggs, but Uye \& Fleminger (1976) suggested that they may be normal eggs which are merely inhibited from hatching by environmental factors. Landry (1978) found no evidence for resting eggs either.

Female Centropages hamatus were absent from the water column for approximately 6 mo from November to April. Most likely this species overwinters as resting eggs in the North Sea (Lindley 1986, 1990), although in the Kattegat it reproduces year round (Kiørboe \& Nielsen 1994).

Centropages typicus was only abundant during 5 mo (September to January), but spawned mainly in September and October. This is similar to its behaviour in the Kattegat (Kiørboe \& Nielsen 1994). In contrast, in the Mediterranean Sea winter is the main reproductive period of this species (Ianora \& Buttino 1990). Resting eggs were reported by Lindley (1986), but have not been observed by other authors. Therefore it seems likely that $C$. typicus is advected into the southern North Sea every year.

When comparing the limited data on regional variability of the reproductive activity of Acartia clausi, Centropages hamatus and C. typicus during winter, a strong gradient becomes apparent. In warmer waters the main spawning season is winter, while at Helgoland Roads none of the species spawned in winter. In the Kattegat, at least during the study of Kiørboe \& Nielsen (1994), the spawning season of A. clausi was longer, and $C$. hamatus continuously spawned there. Water temperatures were approximately $5^{\circ} \mathrm{C}$ warmer in their study period than in our study. If temperature were indeed the controlling factor for reproductive activity, strong interannual variability in the duration of the reproductive period would be expected.

\section{Control of egg production}

There were large differences in overwintering strategies at Helgoland Roads, but the timing of peak egg production in May/June was very similar in all species except the late-arriving Centropages typicus. Egg production rates recorded here were comparable to those found in other field studies, but the timing of the egg production maximum was often quite different. Thus, in their annual study in the Kattegat, Kiørboe \& Nielsen (1994) observed several synchronous maxima of all species investigated, the first in March, when Temora longicornis produced 50 eggs female $\mathrm{f}^{-1} \mathrm{~d}^{-1}$. This is very similar to Long Island Sound, where 50 eggs female $\mathrm{d}^{-1} \mathrm{~d}^{-1}$ were recorded in March by Peterson \& Bellantoni (1987). In March in Helgoland, T. longicornis laid only between 11 and 20 eggs female $\mathrm{e}^{-1} \mathrm{~d}^{-1}$. The maximum rate there (62 eggs female $\mathrm{f}^{-1} \mathrm{~d}^{-1}$ ), however, is similar to maxima in the other studies. In August, fewer eggs (average 6.3 eggs female ${ }^{-1} \mathrm{~d}^{-1}$ ) were produced in the Skagerrak (Peterson et al. 1991) than at Helgoland (16 eggs female ${ }^{-1}$ $\mathrm{d}^{-1}$ ). Bautista et al. (1994) recorded only 20 eggs female $^{-1} \mathrm{~d}^{-1}$ in spring off the southwest coast of England.

Acartia clausi showed maximum egg production rates of 26 eggs female ${ }^{-1} \mathrm{~d}^{-1}$ in July 1995 and 33 eggs female $e^{-1} d^{-1}$ in June 1996, which compare well with the maximum values in other parts of the North Sea (review in Tiselius et al. 1991). Peterson et al. (1991) recorded an average of 7.6 eggs female ${ }^{-1} \mathrm{~d}^{-1}$ in the Skagerrak in August, similar to our measurements at that time (5 to 22 eggs female $\mathrm{d}^{-1} \mathrm{~d}^{-1}$ ). As in the Kattegat (Kiørboe \& Nielsen 1994), in the Mediterranean Sea the annual maximum occurred in February/March, with egg production rates similar to those seen in the North Sea (Ianora \& Scotto di Carlo 1988).

Our egg production rates for Centropages hamatus (maximum 95 eggs female ${ }^{-1} \mathrm{~d}^{-1}$ ) were higher than those seen in other parts of the North Sea (review in Tiselius et al. 1991), and the 70 eggs female ${ }^{-1} \mathrm{~d}^{-1}$ observed by Kiørboe \& Nielsen (1994) in the Kattegat. C. typicus in our study produced at most 35 eggs female ${ }^{-1} \mathrm{~d}^{-1}$ in 
September. Comparable rates were found previously in the North Sea by Kiørboe \& Johansen (1986), who observed a maximum of 25 eggs female ${ }^{-1} \mathrm{~d}^{-1}$ at the same time. In contrast, Peterson et al. (1991) registered 50 to 120 eggs female ${ }^{-1} \mathrm{~d}^{-1}$ (average 91.3 eggs female ${ }^{-1}$ $\mathrm{d}^{-1}$ ) in the Skagerrak in August, and Kiørboe \& Nielsen (1994) mesasured >90 eggs female ${ }^{-1} \mathrm{~d}^{-1}$ in the Kattegat. In the Mediterranean Sea much higher rates have often been observed (review in Carlotti et al. 1997).

Pseudocalanus spp. usually deposits between 1 and 10 eggs per clutch (McLaren 1965, Corkett \& Mclaren 1969, Paffenhöfer \& Harris 1976, Dagg 1978). For the North Sea, Kiørboe \& Johansen (1986) reported 0.5 eggs female $^{-1} \mathrm{~d}^{-1}$ in September, Bautista et al. (1994) recorded a maximum of 12 eggs female $\mathrm{e}^{-1} \mathrm{~d}^{-1}$ in spring. This corresponds well with the maximum of 11 eggs female $\mathrm{d}^{-1}$ at Helgoland.

In general, for these species the timing of the spawning maximum is coincident with phytoplankton blooms in spring and autumn (Landry 1978, Peterson \& Bellantoni 1987, Nielsen 1991, Kiørboe \& Nielsen 1994). Of the regions studied so far, Helgoland seems to be the only exception, although the spring bloom there takes place at more or less the same time as in the other regions. What is the reason for this obvious decoupling?

Laboratory studies have clearly shown that egg production in calanoid copepods is mainly controlled by temperature, food and body size (e.g. Runge 1985, Smith \& Lane 1985, Kimoto et al. 1986, Fryd et al. 1991, Hirche et al. 1997). However, in mid-latitudes the strong annual variability of temperature makes it often difficult to discern the effects of these factors independently. Thus, Landry (1978) showed that the expected increase in fecundity of Acartia clausi due to increasing temperature during the summer was overridden by the large decrease in female size. It has long been known that body size in crustaceans is a major factor determining potential egg mass (Jensen 1958, McLaren 1965, Dagg 1978). Annual cycles in body length are well documented for temperate calanoid copepods (e.g. Conover 1956, Deevey 1960, Gaudy 1972, Evans 1977, Landry 1978) and have been negatively correlated with temperature and positively with phytoplankton abundance (Deevey 1960). At Helgoland Roads, prosome length followed the predicted pattern with temperature, i.e. the smallest size at the highest temperatures. The lag between temperature and body size (Fig. 5) is explained by the fact that temperature during development rather than temperature at collection determines size. A positive correlation of egg production and body size has been shown in many calanoid copepod species including Calanus finmarchicus (Runge 1985, Hirche 1996), Eurytemora affinis (Hirche 1992) and A. clausi (Landry 1978). In Pseudo- calanus spp., the total volume of eggs in a sac is predictable from female size alone, and appears to be unaffected by food supply (Corkett \& McLaren 1969).

The good agreement between the annual cycle of fecundity and prosome length and the weak correlation with food parameters at Helgoland Roads suggests that here body size was the main controlling factor, while food was apparently not limiting during the growth season. Consequently, as at Helgoland Roads during the spring bloom, females were still small, and their egg production rates were lower than those of the larger females found 1 or 2 mo later. Furthermore, the significant correlations between egg production rates of several species (Table 1) indicate equally sufficient feeding conditions for all these species. Similar correlations were obtained in the Kattegat with 5 species of calanoid copepods, but there significant egg production was related to high concentrations of diatoms and other large phytoplankters and, between blooms, egg production was food-limited (Kiørboe \& Nielsen 1994). Food limitation of egg production in coastal waters has also been observed by Checkley (1980), Peterson (1985), Beckman \& Peterson (1986), Kiørboe \& Johansen (1986) and Kiørboe et al. (1988).

The delay of the maximum in secondary production relative to the spring bloom in the southern North Sea may have strong consequences on the fate of the organic production and on the higher trophic levels. Thus, Fransz \& Gieskes (1984) observed an imbalance between copepod grazing and primary production in spring and fall in the North Sea, which must lead to a loss of energy potentially available to higher trophic levels. Other workers have noted that a large proportion of the spring bloom in coastal environments does not enter the pelagic food web but, rather, sediments out of the water column and enters the benthic food web (Smetacek et al. 1978, Walsh 1983). Strong interannual variability in the timing of copepod reproduction due to temperature variability may cause varying degrees of mismatch between the occurrence of fish larvae and their prey, unless temperature affects fish spawning in a similar direction. If, indeed, reproduction in the southern North Sea is under the control of a single factor, predictions of climate-induced changes of copepod reproduction are relatively easy. This hypothesis should be tested further.

Acknowledgements. We gratefully appreciate the cooperation and help of the staff at the 'Biologische Anstalt Helgoland', who organized the plankton sampling and placed laboratory cold rooms and experimental devices at our disposal. Temperature and phytoplankton measurements were provided by the 'Biologische Anstalt Helgoland'; we appreciate their help. This is publication no. 1766 of the AlfredWegener Institute for Polar and Marine Research, Bremerhaven. 


\section{LITERATURE CITED}

Ambler JW (1986) Effect of food quantity and quality on egg production of Acartia tonsa Dana from East Lagoon, Galveston Texas. Estuar Coast Shelf Sci 23:183-196

Ban S (1994) Effect of temperature and food concentration on post-embryonic development, egg production and adult body size of Calanoid copepod Eurytemora affinis. J Plankton Res 16:721-735

Banner FT, Collins MB, Massie KS (1980) The north-west European Shelf seas: the sea bed and the sea in motion. II. Physical and chemical oceanography, and physical resources. Elsevier Scientific Publishing Company, New York

Bautista B, Harris RP, Rodriguez V, Guerrero F (1994) Temporal variability in copepod fecundity during two different spring bloom periods in costal waters off Plymouth (SW England). J Plankton Res 16:1367-1377

Beckman BR, Peterson WT (1986) Egg production by Acartia tonsa in Long Island Sound. J Plankton Res 8:917-925

Carlotti F, Rey C, Javanshir A, Nival S (1997) Laboratory studies on egg and faecal pellet production of Centropages typicus: effect of age, effect of temperature, individual variability. J Plankton Res 19:1143-1165

Checkley DM (1980) Food limitation of egg production by a marine, planktonic copepod in the sea off southern California. Limnol Oceanogr 25:991-998

Conover RJ (1956) Biology of Acartia clausi and Acartia tonsa. Bull Bingham Oceanogr Coll 15:156-230

Corkett CJ, McLaren IA (1969) Egg production and oil storage by the copepod Pseudocalanus in the laboratory. J Exp Mar Biol Ecol 3:90-105

Corkett CJ, McLaren IA (1978) The biology of Pseudocalanus. Adv Mar Biol 15:1-231

Daan R (1989) Factors controlling the summer development of copepod populations in the southern bight of the North Sea. Neth J Sea Res 23:305-322

Dagg MJ (1978) Estimated 'in situ' rates of egg production for the copepod Centropages typicus (Krøyer) in the New York Bight. J Exp Mar Biol Ecol 34:183-196

Davis CC (1976) Overwintering strategies of common planktic copepods in some North Norway fjords and sounds. Astarte 9:37-42

Deevey GB (1960) Relative effects of temperature and food on seasonal variations in length of marine copepods in some eastern American and western European waters. Bull Bingham Oceanogr Coll 17:54-85

Eriksson S (1973) The biology of marine planktonic copepods on the west coast of Sweden. ZOON 1:37-68

Evans F (1977) Seasonal density and production estimates of the commoner planktonic copepods of Northumberland coastal waters. Estuar Coast Mar Sci 5:221-223

Fransz HG (1975) The spring development of calanoid copepod populations in Dutch coastal waters as related to primary production. In: Persoone G, Jaspers E (eds) Proc 10th Eur Mar Biol Symp, Vol 2. Universa Press, Wetteren, p 247-269

Fransz HG (1983a) Zooplankton species of the Wadden Sea. In: Wolff WJ (ed) Marine zoology, ecology of the Wadden Sea. 4. Invertebrata. Balkema, Rotterdam, p 12-23

Fransz HG (1983b) Quantitative data on the plankton of the Wadden Sea proper. In: Wolff WJ (ed) Ecology of the Wadden Sea. 4. Invertebrata. Balkema, Rotterdam, p 125-134

Fransz HG, Gieskes WWC (1984) The unbalance of phytoplankton and copepods in the North Sea. Rapp P-V Réun Cons Int Explor Mer 183:218-225

Fransz HG, van Arkel WG (1983) Fluctuation and succession of common pelagic copepod species in the Dutch Wadden Sea. In: Cabioch L (ed) Oceanol Acta (Vol Spéc). Proc 17th Eur Mar Biol Symp, Brest

Fransz HG, Colebrook JM, Gamble JC, Krause M (1991) The zooplankton of the North Sea. Neth J Sea Res 28:1-52

Frost BW (1989) A taxonomy of the marine calanoid copepod genus Pseudocalanus. Can J Zool 67:525-551

Fryd M, Haslund OH, Wohlgemuth O (1991) Development, growth and egg production of the two copepod species Centropages hamatus and Centropoages typicus in the laboratory. J Plankton Res 13:683-689

Gaudy R (1972) Contribution à la connaissance du cycle biologique des copépodes du Golfe de Marseille. 2. Étude du cycle biologique des quelques espèces charactéristiques. Téthys 4:175-242

Goldberg ED (1973) North Sea science. Part I. Massachusetts Institute of Technology Press, Cambridge

Hart RC, McLaren IA (1978) Temperature acclimation and other influences on embryonic duration in the copepod Pseudocalanus sp. Mar Biol 45:23-30

Hay S (1995) Egg production and secondary production of common North Sea copepods: field estimates with regional and seasonal comparisons. ICES J Mar Sci 52:315-327

Hickel W (1975) The mesozooplankton in the Wadden Sea of Sylt (North Sea). Helgol Wiss Meeresunters 27:254-262

Hickel W (1998) Temporal variability of micro- and nanoplankton in the German Bight in relation to hydrographic structure and nutrient changes. ICES J Mar Sci 55:600-609

Hickel W, Eickhoff E, Spindler H, Berg J, Raabe T, Müller R (1997) Auswertung von Langzeit-Untersuchungen von Nährstoffen und Phytoplankton in der Deutschen Bucht. Umweltbundesamt, Berlin

Hirche HJ (1992) Egg production of Eurytemora affiniseffect of k-strategy. Estuar Coast Shelf Sci 35:395-407

Hirche HJ (1996) The reproductive biology of the marine copepod, Calanus finmarchicus-a review. Ophelia 44: 111-128

Hirche HJ, Meyer U, Niehoff B (1997) Egg production of Calanus finmarchicus: effect of temperature, food and season. Mar Biol 127:609-620

Ianora A, Buttino I (1990) Seasonal cycles in population abundances and egg production rates in the planktonic copepods Centropages typicus and Acartia clausi. J Plankton Res 12:473-481

Ianora A, Scotto di Carlo B (1988) Observations on egg production rates and seasonal changes in the internal morphology of Mediterranean populations of Acartia clausi and Centropages typicus. Hydrobiologia 167/168:247-253

Jensen JP (1958) The relation between body size and number of eggs in marine malacostrakes. Medd Dan Fisk-Havunders (NS) 11:1-25

Kasahara S, Uye S, Onbé T (1974) Calanoid copepod eggs in sea-bottom muds. Mar Biol 26:167-171

Kimoto K, Uye SI, Onbé T (1986) Egg production of a brackish-water calanoid copepod Sinocalanus tenellus in relation to food abundance and temperature. Bull Plankton Soc Jpn 33:133-145

Kiørboe T, Johansen K (1986) Studies of a larval herring (Clupea harengus L.) patch in the Buchan area. IV. Zooplankton distribution and productivity in relation to hydrographic features. Dana 6:37-51

Kiørboe T, Nielsen TG (1994) Regulation of zooplankton biomass and production in a temperate, coastal ecosystem. 1. Copepods. Limnol Oceanogr 39:493-507

Kiørboe T, Munk P, Richardson K, Christensen V, Paulsen H (1988) Plankton dynamics and larval herring growth, drift and survival in a frontal area. Mar Ecol Prog Ser 44:205-219 
Krause M, Dippner JW, Beil J (1995) A review of hydrographic controls on the distribution of zooplankton biomass and species in the North Sea with particular reference to a survey conducted in January-March 1987. Prog Oceanogr 35:81-152

Landry MR (1978) Population dynamics and production of a planktonic marine copepod, Acartia clausii, in a small temperate lagoon on San Juan Island, Washington. Int Rev Ges Hydrobiol 63:77-119

Lindley JA (1986) Dormant eggs of calanoid copepods in seabed sediments of the English Channel and southern North Sea. J Plankton Res 8:399-400

Lindley JA (1990) Distribution of overwintering calanoid copepod eggs in sea-bed sediments around southern Britain. Mar Biol 104:209-217

McLaren IA (1965) Some relationships between temperature and egg size, body size, development rate and fecundity of the copepod Pseudocalanus. Limnol Oceanogr 10:528-538

Mullin MM, Brooks ER (1970) The effect of concentration of food on body weight, cumulative ingestion, and rate of growth of the marine copepod Calanus helgolandicus. Limnol Oceanogr 15:748-755

Niehoff B, Klenke U, Hirche HJ, Irigoien X, Head R, Harris RP (1999) A high frequency time series at Weathership $M$, Norwegian Sea, during the 1997 spring bloom: the reproductive biology of Calanus finmarchicus. Mar Ecol Prog Ser 176:81-92

Nielsen TG (1991) Contribution of zooplankton grazing to the decline of a Ceratium bloom. Limnol Oceanogr 36(6): 1091-1106

Norrbin MF (1996) Timing of diapause in relation to the onset of winter in the high- latitude copepods Pseudocalanus acuspes and Acartia longiremis. Mar Ecol Prog Ser 142: 99-109

Otto L, Zimmerman JTF, Furnes GK, Mork M, Saetre R, Becker G (1990) Review of the physical oceanography of the North Sea. Neth J Sea Res 26:161-238

Paffenhöfer GA, Harris RP (1976) Feeding, growth and reproduction of the marine planktonic copepod Pseudocalanus elongantus Boeck. J Mar Biol Assoc UK 56:327-344

Parrish KK, Wilson DF (1978) Fecundity studies on Acartia tonsa (Copepoda: Calanoida) in standardized culture. Mar Biol 46:65-81

Editorial responsibility: Otto Kinne (Editor),

Oldendorf/Luhe, Germany
Peterson WT (1985) Abundance, age structure and in situ egg production rates of the copepod Temora longicornis in Long Island Sound, New York. Bull Mar Sci 37:726-738

Peterson WT, Bellantoni DC (1987) Relationships between water-column stratification, phytoplankton cell size and copepod fecundity in Long Island Sound and off central Chile. S Afr J Mar Sci 5:411-421

Peterson WT, Tiselius P, Kiørboe T (1991) Copepod egg production, moulting and growth rates, and secondary production, in the Skagerrak in August 1988. J Plankton Res 13:131-154

Radach G, Berg J, Hagmeier E (1990) Long-term changes of the annual cycles of meteorological, hydrographic, nutrient and phytoplankton time series at Helgoland and LV Elbe 1 in the German Bight. Cont Shelf Res 10:305-328

Raymont JEG (1983) Plankton and productivity in the oceans. Vol II. Zooplankton. Pergamon Press, Oxford

Runge JA (1984) Egg production of the marine, planktonic copepod, Calanus pacificus Brodsky: laboratory observations. J Exp Mar Biol Ecol 74:53-66

Runge JA (1985) Relationship of egg production of Calanus pacificus to seasonal changes in phytoplankton availability in Puget Sound, Washington. Limnol Oceanogr 30: 382-396

Smetacek VK, von Bröckel K, Zeitschel B, Zenk W (1978) Sedimentation of particulate matter during a phytoplankton spring bloom in relation to the hydrographical regime. Mar Biol 47:211-226

Smith SL, Lane PVZ (1985) Laboratory studies of the marine copepod Centropages typicus: egg production and development rates. Mar Biol 85:153-162

Tiselius P, Nielsen TG, Breuel G, Jaanus A, Korshenko A, Witek Z (1991) Copepod egg production in the Skagerrak during SKAGEX, May-June 1990. Mar Biol 111:445-453

Uye SI (1981) Fecundity studies of neritic calanoid copepods Acartia clausi Giesbrecht and A. steueri Smirnov: a simple empirical model of daily egg production. J Exp Mar Biol Ecol 50:255-271

Uye SI, Fleminger A (1976) Effect of various environmental factors on egg development of several species of Acartia in Southern California. Mar Biol 38:253-262

Walsh JJ (1983) Death in the sea: enigmatic phytoplankton losses. Prog Oceanogr 12:1-86

Submitted: October 26, 1999; Accepted: June 8, 2000

Proofs received from author(s): November 29, 2000 